\title{
Effects of a Bacteria-Based Probiotic on Ruminal pH, Volatile Fatty Acids and Bacterial Flora of Holstein Calves
}

\author{
Abdul Qadir QADIS ${ }^{1,2)}$, Satoru GOYA ${ }^{3)}$, Kentaro IKUTA $^{4)}$, Minoru YATSU ${ }^{5)}$, Atsushi KIMURA ${ }^{1)}$, \\ Shusuke NAKANISHI ${ }^{6)}$ and Shigeru $\mathrm{SATO}^{1,3) *}$ \\ 1) United Graduate School of Veterinary Science, Gifu University, Gifu 501-1193, Japan \\ ${ }^{2)}$ Faculty of Veterinary Science, Kabul University, Jamal Mina Kabul, Afghanistan \\ ${ }^{3)}$ Cooperative Department of Veterinary Medicine, Faculty of Agriculture, Iwate University, Morioka, Iwate 020-8550, Japan \\ 4) Awaji Agricultural Technology Center, Minami-Awaji, Hyogo 656-0442, Japan \\ ${ }^{5)}$ Miyagi Prefectural Federation of Agricultural Mutual Aid Associations, Shiroishi, Miyagi 989-0731, Japan \\ ${ }^{6)}$ Miyarisan Pharmaceutical Research Laboratory, Nagano 389-0682, Japan
}

(Received 15 January 2014/Accepted 21 February 2014/Published online in J-STAGE 7 March 2014)

ABSTRACT. Twelve ruminally cannulated Holstein calves (age, $12 \pm 3$ weeks) were used to identify the effect of a probiotic comprised of Lactobacillus plantarum, Enterococcus faecium and Clostridium butyricum on ruminal components. The calves were adapted to a diet containing a $50 \%$ high-concentrate (standard diet) for 1 week, and then, the probiotic was given once daily for 5 days (day 1-5) at 1.5 or $3.0 \mathrm{~g} / 100 \mathrm{~kg}$ body weight to groups of four calves each. Four additional calves fed the standard diet without probiotic served as the corresponding control. Ruminal $\mathrm{pH}$ was measured continuously throughout the 15 -day experimental period. Ruminal fluid was collected via a fistula at a defined time predose and on days 7 and 14 to assess volatile fatty acid (VFA), lactic acid and ammonia-nitrogen concentrations, as well as the bacterial community. The probiotic at either dose improved the reduced 24-hr mean ruminal $\mathrm{pH}$ in calves. The circadian patterns of the $1 \mathrm{hr}$ mean ruminal $\mathrm{pH}$ were identical between the probiotic doses. In both probiotic groups, ruminal lactic acid concentrations remained significantly lower than that of the control. Probiotic did not affect ruminal VFA concentrations. L. plantarum and C. butyricum were not detected in the rumen of calves given the high-dose probiotic, whereas Enterococcus spp. remained unchanged. These results suggest that calves given a probiotic had stable ruminal $\mathrm{pH}$ levels (6.6-6.8), presumably due to the effects of the probiotic on stabilizing rumen-predominant bacteria, which consume greater lactate in the rumen.

KEY WORDS: calf, probiotic, ruminal bacteria, ruminal $\mathrm{pH}$.

doi: 10.1292/jvms.14-0028; J. Vet. Med. Sci. 76(6): 877-885, 2014

Bacteria-based probiotics are comprised of a variable number of species and strains of beneficial bacteria known to have positive implications on animal health and performance. In cattle, bacterial probiotic has shown to improve the rumen-predominant microorganisms $[8,12]$ and ruminal performance [27]. Probiotic consisting lactic-acid-producing bacteria $(\mathrm{LAB})$ promote the stability of the rumen flora $[3$, $8,12,40]$, which result in increased dry matter intake and weight gain and improved health in cattle $[6,38]$. Among $\mathrm{LAB}$, the species used most frequently as probiotics are $\mathrm{Lac}$ tobacillus plantarum and Enterococcus faecium [39]. Nocek et al. [27] reported the decreased risk of acidosis for dairy cows receiving a combination of probiotic including Lactobacillus and Enterococcus. Furthermore, steers receiving a probiotic including both lactate-utilizing Propionibacterium and lactate-producing Enterococcus had higher ruminal concentration of acetate, and the blood variables indicated a reduced risk of metabolic acidosis [12]. It has been hy-

*Correspondence to: Sato, S., Cooperative Department of Veterinary Medicine, Faculty of Agriculture, Iwate University, Morioka, Iwate 020-8550, Japan. e-mail: sshigeru@iwate-u.ac.jp

(C)2014 The Japanese Society of Veterinary Science

This is an open-access article distributed under the terms of the Creative Commons Attribution Non-Commercial No Derivatives (by-nc-nd) License $<$ http://creativecommons.org/licenses/by-nc-nd/3.0/>. pothesized that the functionality and efficacy of bacterial probiotics can be determined by their effect on rumen microbial populations $[8,12]$. This thinking is consistent with previous reports that probiotics improve the gastrointestinal tract microbiota in calves $[6,38]$.

Ruminal components, such as $\mathrm{pH}$ and amounts of volatile fatty acids (VFA) and lactic acid, are important environmental factors for survival of ruminal microorganisms $[19,25$, 32]. Decreased $\mathrm{pH}$ and overgrowth of acidophilic bacteria in ruminal fluid are synchronized with an increased level of rapidly fermentable carbohydrate, which results in prompt production and accumulation of ruminal VFAs and lactic acid, leading to acidosis [5, 25]. Likewise, a number of ruminal bacteria, such as fibrolytic bacteria, decrease when the ruminal $\mathrm{pH}$ remained under 5.5 [17, 24, 32]. Orderly shifts occur among the rumen-predominant amylolytic and lactate-utilizing bacterial populations in response to gradually decreasing ruminal $\mathrm{pH}$ [27]. Similarly, when quantities of rapidly fermentable carbohydrates exceed the buffering capacity of the rumen [34], accumulated VFA and lactic acid are associated with a decreased ruminal $\mathrm{pH}[2,32]$, even in newborn calves [15].

Highly fermentable diets stimulate ruminal microbial proliferation and VFA production in pre-weaned calves, followed by initiation of ruminal development [18]. Rapid fermentation of ingested calf starter causes an increased 
concentration of VFA and decreased $\mathrm{pH}$ in the incompletely developed rumen $[15,30]$. Furthermore, consumption of a highly fermentable diet results in increased lactic acid levels and ruminal acidosis in weaned calves $[1,30]$. Challenges, such as the transitive ruminal microbiome and highconcentrate feeding strategies, are related to the incidence of ruminal acidosis in young ruminants [15]. Methods, such as terminal-restriction-fragment length polymorphism (TRFLP), PCR-denaturing gradient gel electrophoresis and real-time analyses of the ruminal flora, show that the most complex interactions occur between the ruminal bacteria and other bacterial products [11, 14, 19]. However, little information on the effect of probiotics containing LAB on ruminal $\mathrm{pH}, \mathrm{VFA}$ and the properties of rumen bacterial flora in calves is available. Furthermore, the mechanism underlying the effects of probiotics on ruminal components remains unclear. The objective of this study was to determine whether administration of a probiotic containing LAB affects the ruminal $\mathrm{pH}, \mathrm{VFA}$, lactic acid and ammonia-nitrogen $\left(\mathrm{NH}_{3}-\mathrm{N}\right)$ levels in conjunction with the levels of a number of ruminal bacteria in weaned Holstein calves.

\section{MATERIALS AND METHODS}

Animals and treatment: This experimental design was approved by the Iwate University Laboratory Animal Care and Use Committee (A201026). Twelve ruminally cannulated Holstein bull calves aged $12 \pm 3$ weeks [95 $\pm 2 \mathrm{~kg}$ body weight (BW); mean $\pm \mathrm{SE}$ ] were housed in a $4 \times 5-\mathrm{m}^{2}$, opensided straw bed and naturally ventilated barn at the Cattle Research Center of Iwate University. The calves had been weaned within 4 weeks after birth and fed starter pellets containing ground corn. The ruminal cannula (diameter; $5 \mathrm{~cm}$ ) was applied 4 weeks before starting the experiment. One week before start of the experiment, the calves were gradually adapted to the high-grain diet containing steam-rolled corn mixed with timothy hay (standard diet). The concentrate: hay ratio was 1:1. The percentages of ingredients and chemical composition of the total mixed diet are shown in Table 1. During the 15-day experimental period, each calf received $3.2 \mathrm{~kg}$ of diet twice per day at $0800 \mathrm{hr}$ and $1700 \mathrm{hr}$ and had access to fresh water ad libitum.

A probiotic (Miyarisan Pharmaceutical Co., Ltd., Tokyo, Japan), which included L. plantarum strain $220\left[9 \times 10^{6}\right.$ colony forming units (CFU)/g], E. faecium strain $26\left(9 \times 10^{5}\right.$ $\mathrm{CFU} / \mathrm{g})$ and Clostridium butyricum strain Miyari $\left(9 \times 10^{4}\right.$ $\mathrm{CFU} / \mathrm{g}$ ), was administered daily as a single dose of 1.5 or 3.0 $\mathrm{g} / 100 \mathrm{~kg} \mathrm{BW}$ to each group of four calves for 5 consecutive days. Four additional calves fed the standard diet without probiotic served as the control. The probiotic was stored at $4^{\circ} \mathrm{C}$, each dose was mixed with $50 \mathrm{~m} l$ of tap water in a beaker, and the probiotic suspension was orally administered to each calf with a $50-\mathrm{m} l$ drencher the morning prior to feeding. No changes in the health of the calves were observed during the experimental period.

Ruminal pH measurement: Ruminal $\mathrm{pH}$ was measured using a radio transmission system, as reported previously [36]. Briefly, the system consisted of a $\mathrm{pH}$ sensor attached
Table 1. Ingredient and chemical components of diet

\begin{tabular}{lc}
\hline \multicolumn{1}{c}{ Item } & Quantity \\
\hline Ingredients, \% (DM) & \\
Steam-rolled corn & 50.0 \\
Alfalfa pellet & 7.5 \\
Corn grain & 18.0 \\
Wheat bran & 13.5 \\
Soybean meal & 10.0 \\
Dried whey & 1.0 \\
Nutrient components ${ }^{\mathrm{a})}$ & \\
DM, \% & 87.8 \\
CP, \% & 17.7 \\
NDF, \% & 40.5 \\
NFC, \% & 28.7 \\
Calcium, \% & 0.50 \\
Phosphorus, \% & 0.35 \\
\hline a) All except DM presented on DM basis. DM presented \\
as percent fed basis.
\end{tabular}

to a transmitter through a $60-\mathrm{cm}$ wire, a data measurement receiver and a personal computer with special software (YCOW-S; DKK-Toa Yamagata, Yamagata, Japan). The pH sensor was inserted through the ruminal cannula and located in the ventral sac of the rumen, and a small data transmitter was mounted at the back of each calf. The standardized site for measuring ruminal $\mathrm{pH}$ is the (cranial-) ventral sac, because most mixing of ruminal contents occurs at this site, and the $\mathrm{pH}$ values are more stable compared to at other ruminal sites [10]. The $\mathrm{pH}$ sensors were calibrated with $\mathrm{pH} 4$ and 7 buffer solutions before insertion and within two weeks interval during the experimental period. Ruminal $\mathrm{pH}$ was recorded every 10 min at 1 week before experiment and during the 15-day experimental period. The location of the $\mathrm{pH}$ sensor in the rumen was checked each morning.

Ruminal fluid sampling and VFA, lactic acid and $\mathrm{NH}_{3}-\mathrm{N}$ assays: Ruminal fluid was collected from the ventral sac of the rumen, adjacent to the $\mathrm{pH}$ sensor. A manual vacuum pump was used to collect samples through the ruminal cannula, the morning prior to feeding, at predose and on days 7 and 14. Ruminal fluid was filtered immediately through two layers of cheesecloth and collected into a sterile plastic tube to analyze ruminal bacteria, total and individual VFA components (acetic acid, propionic acid and butyric acid), lactic acid and $\mathrm{NH}_{3}-\mathrm{N}$. Two milliliters of ruminal fluid were immediately stored at $-80^{\circ} \mathrm{C}$ for assessment of the bacterial population. Ten milliliters of ruminal fluid were added to 2 $\mathrm{ml}$ of $25 \%$ metaphosphoric acid in $3 \mathrm{~N} \mathrm{H}_{2} \mathrm{SO}_{4}$ for assay of VFA. Total and individual VFA components were separated and quantified by gas chromatography (model GC-2014, Shimazu, Kyoto, Japan) using a packed-glass column (Thermon-3,000; 3\%) on a Shimalite TPA 60-80 support (Shinwa Chemical Industries Ltd., Kyoto, Japan). For assay of lactic acid, the ruminal fluid was centrifuged immediately at $2,000 \times g$ for $15 \mathrm{~min}$, and concentrations in the supernatant were determined using a commercial kit (F-kit; D-lactate/Llactate, J. K. International, Tokyo, Japan). $\mathrm{NH}_{3}-\mathrm{N}$ levels in ruminal fluid were determined by the steam distillation 
Table 2. Species- and genus-specific primers for the quantification of ruminal bacteria using real-time PCR assay

\begin{tabular}{lllc}
\hline \multicolumn{1}{c}{ Bacteria } & \multicolumn{1}{c}{ Primer } & \multicolumn{1}{c}{ Sequence $\left(5^{\prime}-3^{\prime}\right)$} & Source \\
\hline Lactobacillus plantarum & Sg-Lpla-F & CTCTGGTATTGATTGGTGCTTGCAT & {$[22]$} \\
& Sg-Lpla-R & GTTCGCCACTCACTCAAATGTAAA & \\
Enterococcus spp. & g-Bfra-F & CCCTTATTGTTAGTTGCCATCATT & {$[31]$} \\
& g-Bfra-R & ACTCGGTTGTACTTCCCATTGT & \\
Clostridium butyricum & $209 \mathrm{~F} 25$ & AGTGATTGTCAGTAGTAGACGAGCG & {$[26]$} \\
& R221 & CATGCGCCCTTTGTAGC & \\
Clostridium coccoides & g-Coc-F & AAATGACGGTACCTGACTAA & {$[23]$} \\
& g-Coc-R & CTTTGAGTTTCATTCTTGCGAA & \\
Megasphaera elsdenii & MegEls1F & GACCGAAACTGCGATGCTAGA & {$[13]$} \\
& MegEls1R & CGCCTCAGCGTCAGTTGTC & \\
Selenomonas ruminantium & SelRum1F & GGCGGGAAGGCAAGTCAGTC & {$[13]$} \\
& SelRum1R & CCTCTCCTGCACTCAAGAAAGACAG & \\
\hline
\end{tabular}

method using an automatic-N analyzer (Kjeltec auto sampler system 1035 Analyzer, Tecator, Sweden).

Rumen bacterial flora assay: Bacterial composition of ruminal fluid was assessed using T-RFLP and real-time PCR. The rumen bacterial flora was evaluated in ruminal fluid samples collected at predose and on days 7 and 14 from both the group given 3.0-g probiotic and the control group. Bacterial DNA was extracted from $1 \mathrm{~m} l$ of ruminal fluid using the bead-phenol method [23]. Extracted DNA was dissolved in TE buffer and stored at $-80^{\circ} \mathrm{C}$ until T-RFLP and real-time PCR analyses. T-RFLP measurements were performed according to the method of Sakamoto et al. [35]. In brief, the complete $16 \mathrm{~S}$ rDNA was amplified using the universal primers 27F (5'-AGAGTTTGATCCTGGCTCAG-3') and 1492R (5'-GGTTACCTTGTTACGACTT-3') for PCR amplification of the 16S rRNA gene sequences [16]. The forward primer was labeled at the $5^{\prime}$ end with 6'-carboxyfluorescein (Applied Biosystems, Tokyo, Japan). The following program was used to amplify $16 \mathrm{~s}$ rDNA: $95^{\circ} \mathrm{C}$ for $3 \mathrm{~min}$, followed by 30 cycles of $95^{\circ} \mathrm{C}$ for $30 \mathrm{sec}$ and $72^{\circ} \mathrm{C}$ for $1.5 \mathrm{~min}$, with a final extension at $72^{\circ} \mathrm{C}$ for $10 \mathrm{~min}$. The PCR products were purified using a High Pure PCR Product Purification kit (Roche, Indianapolis, IN, U.S.A.) and digested using either HhaI or $\mathrm{Msp} \mathrm{I}$ at $37^{\circ} \mathrm{C}$ for $3 \mathrm{hr}$. A standardized marker $(1,200$ LIZ) was then added to each sample. The length of the terminal restriction fragment was determined on an ABI PRISM 310 Genetic Analyzer (Applied Biosystems). Fragment sizes were estimated using GeneMapper Software (Applied Biosystems). The predicted T-RFLP patterns of the $16 \mathrm{~S}$ rDNAs of known bacterial species were obtained using InfoCom software (Microbiota Profiler; Infocom Co., Tokyo, Japan).

Bacterial species, including the probiotic and some ruminal bacteria, were quantified by real-time PCR according to a previous method [23]. Briefly, DNA extraction from ruminal fluid samples was performed using a method similar to that for the T-RFLP measurements. Real-time PCR was carried out using a Thermal Cycler Dice TP800 device (Takara, Otsu, Japan), using the primers shown in Table 2. The quantification of DNA for each bacterial species in ruminal fluid was performed using the SYBR Green intercalation procedure. Standards and samples were assayed in a $25-\mu l$ reaction mixture containing $12.5 \mu \mathrm{l}$ of SYBR Premix EX
Taq II (Tli RNase H plus), $0.5 \mu l$ of each primer, $10.5 \mu l$ of nuclease-free water and $1 \mu l$ of DNA template. The amplification program included an initial denaturation step at $95^{\circ} \mathrm{C}$ for $5 \mathrm{~min}$ followed by 40 cycles of denaturation at $95^{\circ} \mathrm{C}$ for $5 \mathrm{sec}$, annealing/extension at $60^{\circ} \mathrm{C}$ for $30 \mathrm{sec}$, with a final extension step at $72^{\circ} \mathrm{C}$ for $5 \mathrm{~min}$.

Statistical analysis: The calf was the experimental unit for all statistical analyses, and the random effect was the calf within a treatment. The main effects included challenge treatment, day of the experiment (predose day $=24 \mathrm{hr}$ before treatment, day $1=0-24 \mathrm{hr}$, followed until day 14) and after $0800 \mathrm{hr}$ treatment and feeding. Diurnal measurements of ruminal $\mathrm{pH}$ were analyzed as $24-\mathrm{hr}$ mean $\mathrm{pH}$ from 1 day before to 14 days after treatment. Each 10-min interval of the $\mathrm{pH}$ data was summarized as a $1-\mathrm{hr}$ mean from $0800 \mathrm{hr}$ to $0700 \mathrm{hr}$ the following day to assess circadian changes. Minimum and maximum $\mathrm{pH}$ values during a single day were determined on the predose day and days 7 and 14. Minimum and maximum $\mathrm{pH}$ values were analyzed by the Mann-Whitney $U$-test. Quantities of 16S rRNA as determined by realtime PCR were analyzed to determine significant differences in copy number between treatment and control groups for each targeted bacterial species. Ruminal parameters and the number of bacteria data are presented as means \pm SE. TRFLP analyses of rumen bacterial flora were expressed on an electropherogram based on the size of the intergenic spacer and the fluorescence intensities of the fragments. Graph Pad Prism ver. 5.01 software (La Jolla, CA, U.S.A.) was used for the statistical calculations, and one-way repeated-measures analysis of variance followed by the Tukey's multiple comparison method was used to evaluate differences among the groups. A $P$-value $<0.05$ was considered significant.

\section{RESULTS}

Ruminal $\mathrm{pH}$ : Ruminal $\mathrm{pH}$ in calves received the probiotic at either dose exhibited a constant 24-hr mean $\mathrm{pH}$ during the experimental period. A difference $(P<0.01)$ in ruminal $\mathrm{pH}$ was found between the probiotic and control groups on days 4 to 14 . In addition, the 24-hr mean ruminal $\mathrm{pH}$ decreased $(P<0.01)$ in the control group on days 5, 9, 10 and 11 compared to predose values. Considerable disparities in 


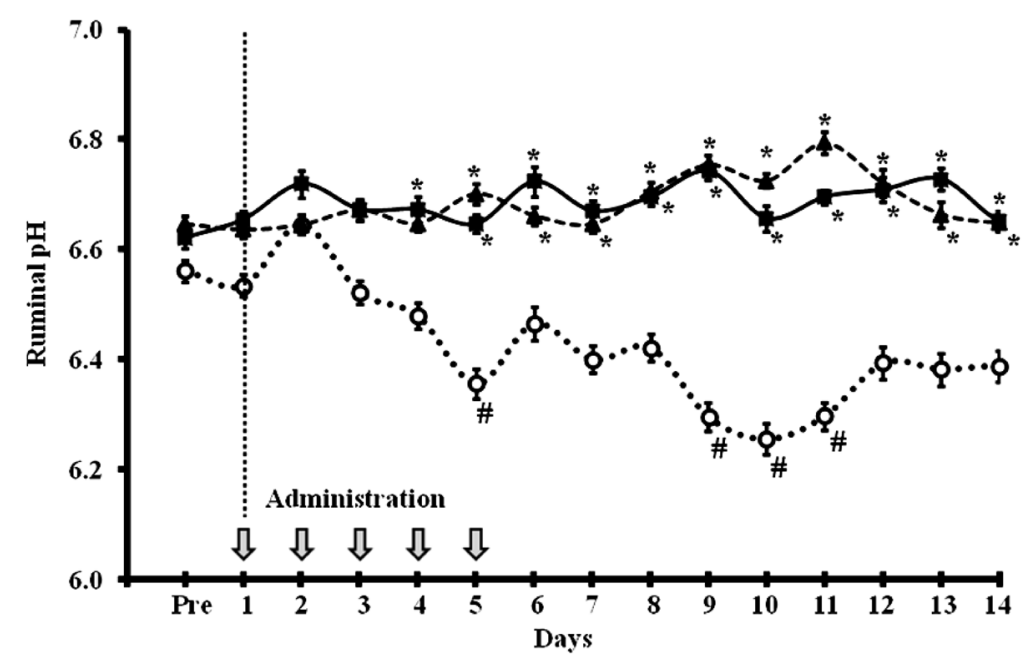

Fig. 1. Changes in 24-hr mean $\mathrm{pH}$ in the ruminal fluid of calves given $1.5 \mathrm{~g}(\mathrm{n}=4$; $\Delta)$ or $3.0 \mathrm{~g} / 100 \mathrm{~kg} \mathrm{BW}(\mathrm{n}=4 ; \boldsymbol{m})$ probiotic for 5 consecutive days. Additional calves without probiotic served as control $(\mathrm{n}=4 ; \circ)$. Values represent the means $\pm \mathrm{SE}$. * Ruminal $\mathrm{pH}$ in the probiotic groups compared to control on the same day $(P<0.01)$. \# Ruminal $\mathrm{pH}$ in the control group compared to the predose day (Pre; $P<0.01$ ). The first day of probiotic administration was regarded as day 1 .

the ruminal $\mathrm{pH}$ values among the probiotic groups and control were observed 3 day after initial administration of the probiotic and continued throughout the experimental period (Fig. 1). The circadian pattern of 1-hr mean $\mathrm{pH}$ was almost identical among the probiotic groups at predose to day 14 . However, a difference $(P<0.01)$ between the $\mathrm{pH}$ values of the probiotic groups and control was observed at similar times on days 7 and 14 . The ruminal $\mathrm{pH}$ decreased approximately 1-hr after feeding of a standard diet in the morning and evening. The 1-hr mean $\mathrm{pH}$ curve in the control on days 7 and 14 differed $(P<0.01)$ from the values at $0800 \mathrm{hr}$ on the same day (Fig. 2). The minimum ruminal $\mathrm{pH}$ was greater $(P<0.05)$ in probiotic groups than that in the control on day 7. On the same day, the minimum $\mathrm{pH}$ in the control calves was different $(P<0.05)$ from that predose. The maximum ruminal $\mathrm{pH}$ values approached 7.0 in the probiotic groups and did not differ from that of control during the experimental period (Fig. 3).

Ruminal VFA, lactic acid and $\mathrm{NH}_{3}-\mathrm{N}$ : No difference in the concentrations of total VFA between the probiotic groups and the control was observed. Concentrations of none of the individual VFA were altered among the groups. The acetic acid and propionic acid ratios were almost identical in all probiotic groups. Lactic acid concentrations remained unchanged in both probiotic groups. However, the lactic acid concentration increased $(P<0.01)$ in the control on day 7 compared to that predose and differed $(P<0.01)$ from the values in the probiotic groups on the same day. No difference in rumen fluid $\mathrm{NH}_{3}-\mathrm{N}$ concentration between the probiotic groups was observed. However, the $\mathrm{NH}_{3}-\mathrm{N}$ concentration was significantly high $(P<0.01)$ in the control group on days 7 and 14, compared to predose day and also the values in the probiotic groups on the same days (Table 3).
Rumen bacterial flora: Ruminal cellulolytic bacteria, such as Butyrivibrio fibriosolvens and Eubacterium ruminantium, showed greater fluorescence intensity peaks in most samples from calves given 3.0-g probiotic on day 7 . The Bacteriodetes group bacteria had greater peaks in the control group on days 7 and 14. However, most bacteria were not detected by T-RFLP measurement in the probiotic group samples on day 14 (Fig. 4). The mean number of L. plantarum by realtime PCR was less than $2 \times 10^{3}$ cells $/ \mathrm{m} l$ in ruminal fluid of probiotic group on days 7 and 14 . In contrast, the number of L. plantarum was unchanged in the control samples on days 7 and 14. The number of Enterococcus spp. remained unchanged in the probiotic and control groups, while C. butyricum was not detected (less than $2 \times 10^{3}$ cells $/ \mathrm{m} l$ of ruminal fluid) in the probiotic groups on days 7 and 14. The numbers of Clostridium coccoides were similar among the groups. The number of Megasphaera elsdenii and Selenomonas ruminantium did not differ among calves given probiotic on days 7 and 14. However, M. elsdenii was slightly changed in the controls on days 7 and 14 (Table 4).

\section{DISCUSSION}

Probiotics have been shown to improve anaerobiosis, stabilise $\mathrm{pH}$ and supply nutrients to ruminal microbes in their microenvironment $[3,7,8,12,21]$. A probiotic consisting of L. plantarum and E. faecium induced a change in the ruminal $\mathrm{pH}$ in cows fed a high grain diet [27]. Ruminal pH decreases immediately after feeding of a high concentrate to adult cattle and newborn calves $[15,34]$. The decrease in ruminal $\mathrm{pH}$ depends on feeding frequency, effective neutral detergent fiber, ruminal digestion rate and absorption of VFA through the ruminal epithelium [2, 29]. Furthermore, changes in 

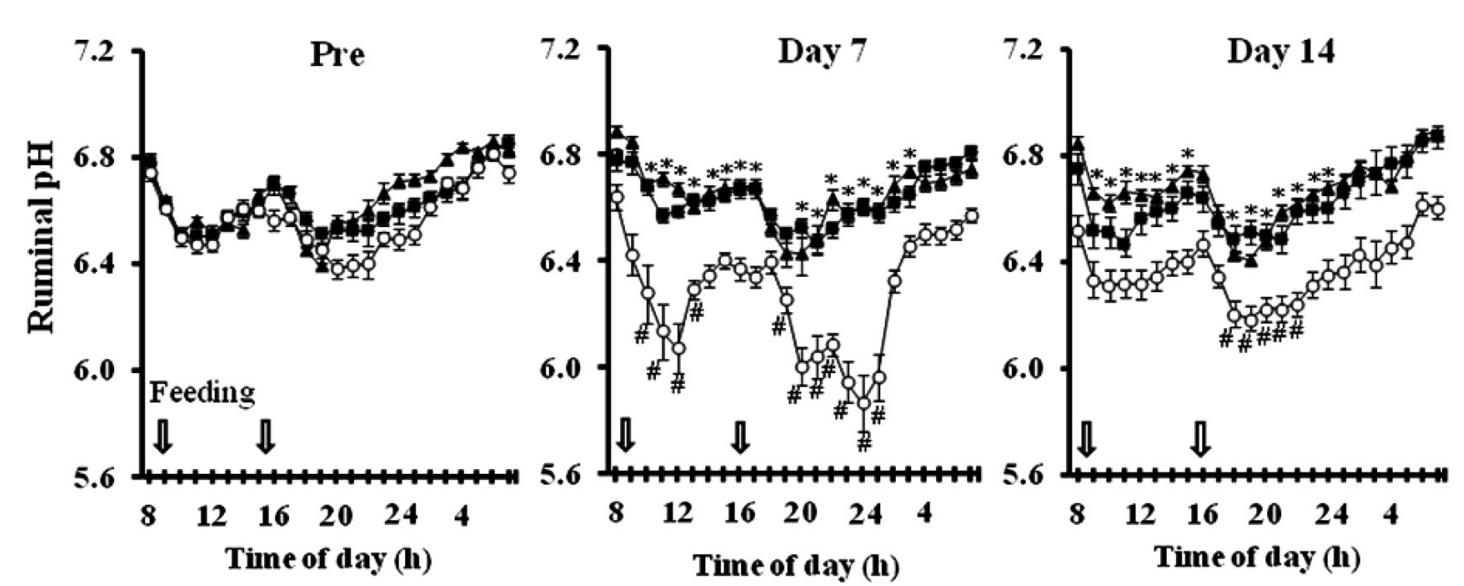

Fig. 2. Circadian changes in 1-hr mean $\mathrm{pH}$ at predose day (Pre) and days 7 and 14 in the ruminal fluid of calves given 1.5 $\mathrm{g}(\mathrm{n}=4 ; \boldsymbol{\Lambda})$ or $3.0 \mathrm{~g} / 100 \mathrm{~kg} \mathrm{BW}(\mathrm{n}=4 ; \boldsymbol{\square})$ probiotic for 5 consecutive days. Additional calves without probiotic served as controls $(\mathrm{n}=4 ; \circ)$. Values represent the means \pm SE. $*$ Ruminal $\mathrm{pH}$ in the probiotic groups compared to the controls at the same time $(P<0.01)$. \# Ruminal $\mathrm{pH}$ in the control group compared to time before feeding $(0800 \mathrm{hr} ; P<0.01)$.


Fig. 3. Box plots showing maximum and minimum ruminal $\mathrm{pH}$ on the predose day (Pre) and days 7 and 14 in calves given $1.5 \mathrm{~g}(\mathrm{n}=4$; grey boxes) or $3.0 \mathrm{~g} / 100 \mathrm{~kg} \mathrm{BW}$ ( $\mathrm{n}=4$; dark boxes) probiotic for 5 consecutive days. Additional calves not given probiotic served as control ( $\mathrm{n}=4$; white boxes). Median and quartiles are displayed in the box. Upper and lower bars represent maximum and minimum values, respectively. * Ruminal $\mathrm{pH}$ in the probiotic groups compared to the controls on the same day $(P<0.05)$. \# Ruminal $\mathrm{pH}$ in the control group compared to the predose day (Pre; $P<0.05$ ). The first day of probiotic administration was regarded as day 1 .

rumen bacterial composition, increased activities of lactateutilizing bacteria and greater lactate consumption also affect ruminal $\mathrm{pH}[13,20,21]$. A stable ruminal $\mathrm{pH}$ may result from decreased fermentation by LAB and other carbohydrate fer- menters, which inhabit low-pH environments [39]. Nocek et al. [27] reported that cows fed fewer probiotic maintained a greater $\mathrm{pH}$ than cows fed high concentration without probiotic, and they suggested that a probiotic consisting of LAB produced sufficient acid to stimulate acid utilizers. By contrast, our results indicate that a LAB-containing probiotic had a marked effect on the ruminal $\mathrm{pH}$ of high-concentrate-fed calves at either dose. In the present study, the ruminal VFA concentration was not affected by the probiotic treatment. This is in agreement with previous reports, in which ruminal VFA was not affected by a probiotic included LAB $[7,12]$. In our study, the VFA concentration was likely affected by sampling time because the total ruminal VFA concentration in calves increases soon after feeding [4], and the majority of VFA present have been absorbed by the following morning $[29,30,34]$. This explains the greater ruminal $\mathrm{pH}$ in calves in the control group in the morning. In addition, the size of the rumen and the effectiveness of ruminal absorption may also affect the ruminal VFA concentration in calves [18].

The lactic acid concentration increased in the control but not in the probiotic groups, and was correlated with a significantly lower mean ruminal $\mathrm{pH}$ in the control group. This indicates that control calves had a normal ruminal fermentation capacity during feeding of high-concentrate, which was supported by the decrease in ruminal $\mathrm{pH}$ and growth of LAB $[15,39]$. However, the circadian ruminal $\mathrm{pH}$ increased gradually in control calves, which may be attributable to the effects of time and adaption to diet [9]. A decrease in ruminal $\mathrm{pH}$ is known to be related to decreased absorption of VFA and the accumulation of lactic acid in the few hours after high grain feeding $[2,13,29]$. Probiotics including LAB affect ruminal $\mathrm{pH}$ by altering the growth of lactate-utilizing bacteria in the rumen [8]. In contrast, the number of lactate-utilizing bacteria increases only when lactic acid accumulates and ruminal $\mathrm{pH}$ decreases $[13,21]$. A common theory is that probiotic may prevent a decline in rumen $\mathrm{pH}$ by decreasing lactic acid production and increasing the utilization of lactic acid by 
Table 3. Ruminal VFA, lactic acid and $\mathrm{NH}_{3}-\mathrm{N}$ concentrations in probiotic-treated and control calves

\begin{tabular}{|c|c|c|c|c|c|c|c|c|c|}
\hline \multirow{3}{*}{ Item } & \multicolumn{6}{|c|}{ Treatment $^{\text {a) }}$} & \multirow{2}{*}{\multicolumn{3}{|c|}{ Control }} \\
\hline & \multicolumn{3}{|c|}{ Probiotic $(1.5 \mathrm{~g})$} & \multicolumn{3}{|c|}{ Probiotic $(3.0 \mathrm{~g})$} & & & \\
\hline & Pre b) & Day 7 & Day 14 & Pre & Day 7 & Day 14 & Pre & Day 7 & Day 14 \\
\hline \multicolumn{10}{|l|}{$\mathrm{VFA}, \mathrm{mmol} / \mathrm{d} l$} \\
\hline Total & $7.5 \pm 0.6$ & $8.1 \pm 0.6$ & $8.0 \pm 0.4$ & $6.8 \pm 0.4$ & $7.6 \pm 0.4$ & $7.4 \pm 0.3$ & $7.7 \pm 0.2$ & $9.2 \pm 0.5$ & $7.6 \pm 0.3$ \\
\hline Acetic acid & $5.3 \pm 0.5$ & $5.8 \pm 0.4$ & $5.6 \pm 0.2$ & $5.0 \pm 0.3$ & $5.3 \pm 0.2$ & $5.1 \pm 0.2$ & $5.3 \pm 0.1$ & $6.5 \pm 0.3$ & $5.2 \pm 0.2$ \\
\hline Propionic acid & $1.4 \pm 0.1$ & $1.5 \pm 0.1$ & $1.5 \pm 0.1$ & $1.3 \pm 0.1$ & $1.5 \pm 0.1$ & $1.5 \pm 0.1$ & $1.5 \pm 0.1$ & $1.8 \pm 0.1$ & $1.5 \pm 0.1$ \\
\hline Butyric acid & $0.6 \pm 0.1$ & $0.7 \pm 0.1$ & $0.7 \pm 0.1$ & $0.5 \pm 0.1$ & $0.6 \pm 0.1$ & $0.6 \pm 0.1$ & $0.6 \pm 0.1$ & $0.8 \pm 0.1$ & $0.7 \pm 0.1$ \\
\hline $\mathrm{A}: \mathrm{P}^{\mathrm{C})}$ & $3.8 \pm 0.2$ & $4.0 \pm 0.1$ & $3.8 \pm 0.1$ & $3.9 \pm 0.1$ & $3.5 \pm 0.1$ & $3.3 \pm 0.1$ & $3.8 \pm 0.2$ & $4.1 \pm 0.1$ & $4.1 \pm 0.2$ \\
\hline Lactic acid, mg/d $l$ & $2.3 \pm 0.3$ & $3.0 \pm 1.1^{*}$ & $2.1 \pm 0.4$ & $2.5 \pm 0.5$ & $2.0 \pm 0.2 *$ & $2.2 \pm 0.0$ & $2.3 \pm 0.1$ & $10 \pm 2.4^{\#}$ & $3.1 \pm 0.1$ \\
\hline $\mathrm{NH}_{3}-\mathrm{N}, \mathrm{mg} / \mathrm{d} l$ & $7.8 \pm 0.8$ & $7.5 \pm 0.6^{*}$ & $8.0 \pm 0.3^{*}$ & $6.2 \pm 0.8$ & $8.1 \pm 0.7^{*}$ & $7.0 \pm 1.0^{*}$ & $6.8 \pm 1.0$ & $13 \pm 1.3^{\#}$ & $12 \pm 1.6^{\#}$ \\
\hline
\end{tabular}

a) Calves of each group received probiotic at 1.5 or $3.0 \mathrm{~g} / 100 \mathrm{~kg} \mathrm{BW}$ per day for 5 days. b) Predose day (day before administration). c) Acetic acid:Propionic acid. Values represent mean $\pm \mathrm{SE}(\mathrm{n}=4)$. ${ }^{*}$ Compared to the control values on the same day $(P<0.01)$. \# Compared to the predose (Pre) values in the same group $(P<0.01)$.
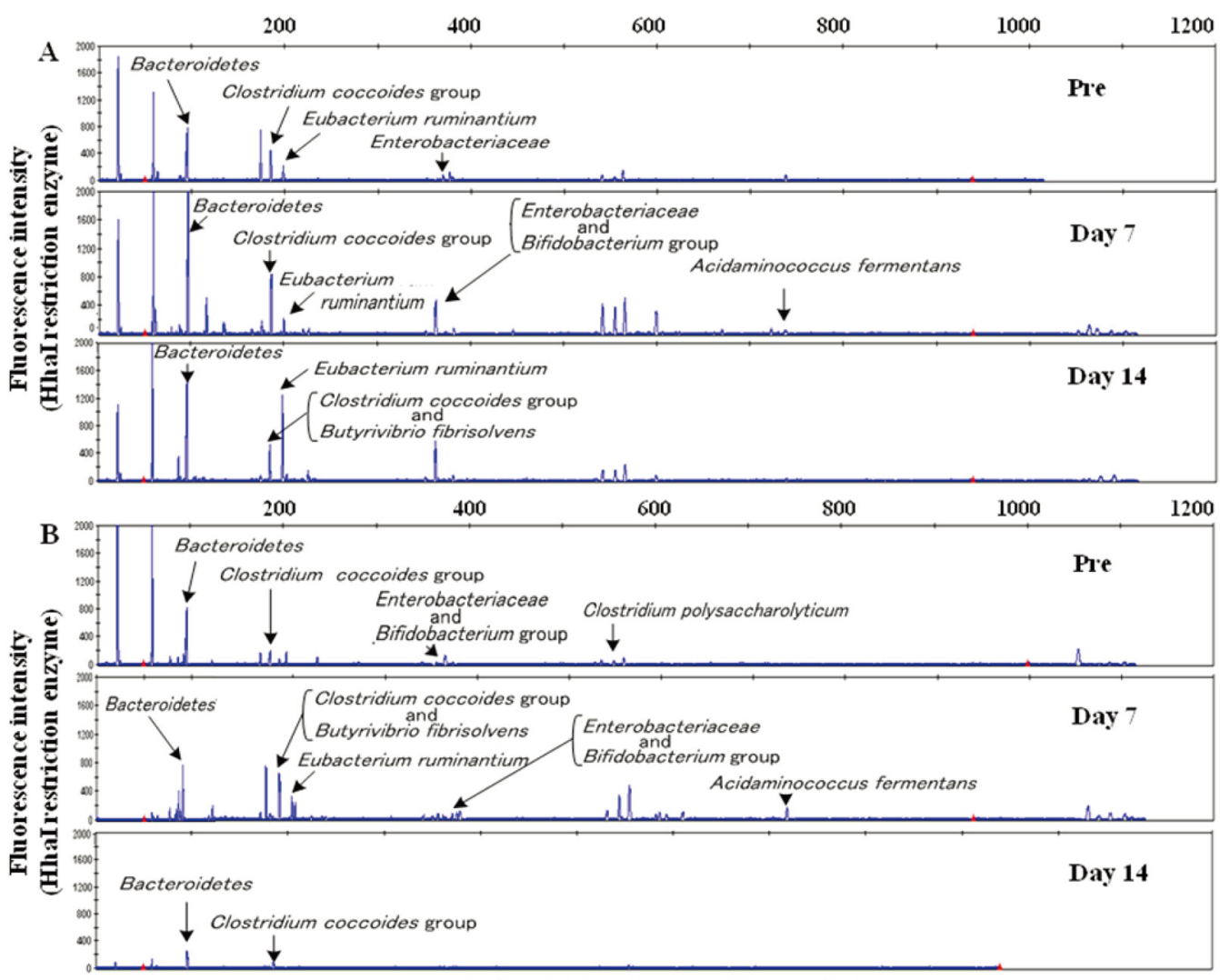

Terminal restriction fragment length (bp)

Fig. 4. Representative terminal-restriction-fragment length polymorphism (T-RFLP) analysis of rumen microbiota composition on the predose day (Pre) and days 7 and 14 in control calves given standard diet without probiotic (A) and the calves given $3.0 \mathrm{~g} / 100 \mathrm{~kg}$ BW probiotic (B). Each peak represents a terminal restriction fragment of a specific length that corresponds to a bacterial phylotype, usually a genus.

some microbes $[3,7,27]$. It is possible that certain probiotic combinations, which synthesize lactic acid, may sustain a tonic level of lactic acid in the rumen. This would stimulate the rumen predominant microbial communities, which consume lactic acid and reduce total acidity, as a consequence the ruminal $\mathrm{pH}$ would remain stable. In the present study, the ruminal concentration of lactic acid and the number of lactate-utilizing bacteria (M. elsdenii) were not affected by probiotic treatment, whereas the number of $M$. elsdenii was greater in the controls. Compared to predose day, the 
Table 4. Enumerated eubacteria 16S rRNA genes of some rumen bacterial species in probiotic-treated and control calves

\begin{tabular}{|c|c|c|c|c|c|c|}
\hline \multirow{2}{*}{ Bacteria } & \multicolumn{3}{|c|}{ Treatment $^{\text {a) }}$} & \multicolumn{3}{|c|}{ Control } \\
\hline & $\operatorname{Pre}^{b)}$ & Day 7 & Day 14 & Pre & Day 7 & Day 14 \\
\hline Lactobacillus plantarum & $2.5 \pm 0.8$ & $\mathrm{ND}^{\mathrm{c})}$ & ND & $2.1 \pm 0.7$ & $2.8 \pm 0.6$ & $2.3 \pm 0.7$ \\
\hline Enterococcus spp. & $4.8 \pm 0.1$ & $4.3 \pm 0.1$ & $4.5 \pm 0.1$ & $4.5 \pm 0.1$ & $4.8 \pm 0.1$ & $5.0 \pm 0.2$ \\
\hline Clostridium butyricum & $2.1 \pm 0.8$ & ND & ND & $2.9 \pm 0.6$ & $2.4 \pm 0.8$ & ND \\
\hline Clostridium coccoides group & $8.8 \pm 0.1$ & $8.7 \pm 0.1$ & $8.9 \pm 0.3$ & $8.8 \pm 0.1$ & $8.7 \pm 0.1$ & $9.0 \pm 0.1$ \\
\hline Megasphaera elsdenii & $4.5 \pm 0.1$ & $5.0 \pm 0.1$ & $5.6 \pm 0.8$ & $4.7 \pm 0.1$ & $6.4 \pm 0.1$ & $6.1 \pm 0.1$ \\
\hline Selenomonas ruminantium & $8.2 \pm 0.2$ & $8.1 \pm 0.2$ & $8.1 \pm 0.1$ & $8.0 \pm 0.3$ & $8.2 \pm 0.3$ & $8.5 \pm 0.1$ \\
\hline
\end{tabular}

a) Calves of group received probiotic at $3.0 \mathrm{~g} / 100 \mathrm{~kg} \mathrm{BW}$ per day for 5 days, and additional calves fed the standard diet without probiotic served as the control. b) Predose day (day before administration). c) Not detected (less than $2 \times 10^{3}$ cells $\left./ \mathrm{m} l\right)$.Values represent number of bacteria $\left(\times 10^{3}\right.$ cells $\left./ \mathrm{m} l\right)$ in ruminal fluids $($ Mean $\pm \mathrm{SE} ; \mathrm{n}=4)$.

$\mathrm{NH}_{3}-\mathrm{N}$ level remained unchanged in the probiotic groups on days 7 and 14, however, the values were significantly lower compared to that of the control group. Probiotics have been reported to have no effects on the $\mathrm{NH}_{3}-\mathrm{N}$ concentration in the rumen $[8,12]$. It was also reported that many cellulolytic bacteria used $\mathrm{NH}_{3}$ as their only source of $\mathrm{N}$ [33]. Therefore, a lower $\mathrm{NH}_{3}-\mathrm{N}$ concentrations and stable ruminal $\mathrm{pH}$ in probiotic treated calves might imply the greater growth of cellulolytic bacteria in the rumen.

The numbers of L. plantarum and Enterococcus spp. did not increase in the ruminal fluid of the probiotic groups. This was likely because growth of $\mathrm{LAB}$ is inhibited at $\mathrm{pH}$ values $>6.0[5,39]$. It has also been suggested that orderly shifts occur among the predominating amylolytic and lactateutilizing bacteria in response to changes in ruminal $\mathrm{pH}$ [20]. Likewise, Russell et al. [33] reported that LAB growth and carbohydrate fermentation are more favorable at lower ruminal $\mathrm{pH}$ values, whereas fiber digestion is enhanced at a ruminal $\mathrm{pH}>6.2$ [32]. According to circadian measurements, ruminal $\mathrm{pH}$ was $<6.6$ during the morning when the probiotic was administered, which is ideal for cellulolytic bacteria [24]. In contrast, the number of $B$. fibrisolvens peaked at a greater level in the most calves given 3.0-g probiotic, based on the T-RFLP measurements; thus, $B$. fibrisolvens is the most active and numerous cellulolytic and acid-sensitive bacterium in the rumen [24,34]. Bacteroidetes-group organisms exhibited high growth rates only in the control group; indeed, these bacteria exhibit a distinctive ability to survive at a range of ruminal $\mathrm{pH}$ [33]. Recently, it was reported that increased amounts of high-concentrate diet and a reduction in ruminal $\mathrm{pH}$ were less favorable to fibrolytic bacteria in the rumen [28]. Furthermore, earlier studies noted that a ruminal $\mathrm{pH}$ of 6.0 to 7.0 facilitated the growth of acid-sensitive ruminal bacteria [14, 33]. A maintaining effect of bacteria-based probiotic on rumen-predominant microorganisms has been reported [12,35]. Sharp et al. [37] reported that L. plantarum and starch-utilizing bacteria were rapidly lost from the rumen due to protozoan predation. Although probiotic products contain fewer surviving organisms, the recommended probiotic composition and dose remain obscure [11]. Such products likely enhance the effects of rumen-predominant microorganisms [40]. However, a possible antagonistic interaction and inhibitory effects among the rumen-predom- inant bacteria and inoculated probiotic strains have also been reported $[8,12]$. Although the mode of action of probiotic in the rumen is not completely understood, the administration of LAB probiotics is thought to help the rumen microflora adapt to the presence of lactic acid [12] and prevent lactate accumulation in rumen $[6,32]$.

In summary, a repeated 5 days administration of a bacterial probiotic resulted in reducing the decrease in ruminal $\mathrm{pH}$ in Holstein calves fed high concentrates. High 24-hr mean ruminal $\mathrm{pH}$ was observed after the probiotic treatment. Although the numbers of bacteria in the probiotic ( $L$. plantarum, Enterococcus spp. and C. butyricum) did not increase in the rumen of calves during the treatment, the numbers of the other rumen-predominant bacterial species were stable. These findings demonstrate the beneficial effects of a probiotic, which are mediated by their influence on the rumen-predominant bacteria. Probiotic supplementation may affect ruminal lactic acid concentration due to increasing lactate consumption, and therefore, the decreased lactic acid concentration resulted in stable ruminal $\mathrm{pH}$ in calves. Further studies using more animals are needed to confirm the effects of such a probiotic on rumen bacterial composition, VFA proportions and lactic acid concentrations in cattle.

ACKNOWLEDGMENTS. We acknowledge the technical support of Dr. Mamoru Tanaka, Dr. Noriko Kobayashi and Dr. Chika Seki in the Research Laboratory of Miyarisan Pharmaceutical.

\section{REFERENCES}

1. Anderson, K. L., Nagaraja, T. G., Morrill, J. L., Avery, T. B., Galitzer, S. J. and Boyer, J. E. 1987. Ruminal microbial development in conventionally or early-weaned calves. J. Anim. Sci. 64: 1215-1226. [Medline]

2. Aschenbach, J. R., Penner, G. B., Stumpff, F. and Gäbel, G. 2011. Ruminant nutrition symposium: Role of fermentation acid absorption in the regulation of ruminal pH. J. Anim. Sci. 89: 1092-1107. [Medline] [CrossRef]

3. Beauchemin, K. A., Yang, W. Z., Morgavi, D. P., Ghorbani, G. R., Kautz, W. and Leedle, J. A. 2003. Effects of bacterial directfed microbials and yeast on site and extent of digestion, blood chemistry, and subclinical ruminal acidosis in feedlot cattle. $J$. Anim. Sci. 81: 1628-1640. [Medline] 
4. Beharka, A. A., Nagaraja, T. G., Morrill, J. L., Kennedy, G. A. and Klemm, R. D. 1998. Effects of form of the diet on anatomical, microbial, and fermentative development of the rumen of neonatal calves. J. Dairy Sci. 81: 1946-1955. [Medline] [CrossRef]

5. Belanche, A., Doreau, M., Edwards, J. E., Moorby, J. M., Pinloche, E. and Newbold, C. J. 2012. Shifts in the rumen microbiota due to the type of carbohydrate and level of protein ingested by dairy cattle are associated with changes in rumen fermentation1-3. J. Nutr. 142: 1684-1692. [Medline] [CrossRef]

6. Callaway, E. S. and Martin, S. A. 1997. Effects of a saccharomyces cerevisiae culture on ruminal bacteria that utilize lactate and digest cellulose. J. Dairy Sci. 80: 2035-2044. [Medline] [CrossRef]

7. Chiquette, J., Allison, J. and Rasmussen, M. A. 2008. Prevotella bryantii $25 \mathrm{~A}$ used as a probiotic in early lactation dairy cows: Effect on ruminal fermentation characteristics, milk production, and milk composition. J. Dairy Sci. 91: 3536-3543. [Medline] [CrossRef]

8. Chiquette, J., Allison, M. J. and Rasmussen, M. 2012. Use of Prevotella bryantii $25 \mathrm{~A}$ and a commercial probiotic during subacute acidosis challenge in midlactation dairy cows. J. Dairy Sci. 95: 5985-5995. [Medline] [CrossRef]

9. Dohme, F., DeVries, T. J. and Beauchemin, K. A. 2008. Repeated ruminal acidosis challenges in lactating dairy cows at high and low risk for developing acidosis: Ruminal p. J. Dairy Sci. 91: 3554-3567. [Medline] [CrossRef]

10. Duffield, T., Plaizier, J. C., Fairfield, A., Bagg, R., Vessie, G., Dick, P., Wilson, J., Aramini, J. and McBride, B. 2004. Comparison of techniques for measurement of rumen $\mathrm{pH}$ in lactating dairy cows. J. Dairy Sci. 87: 59-66. [Medline] [CrossRef]

11. Fasoli, S., Marzotto, M., Rizzotti, L., Rossi, F., Dellaglio, F. and Torriani, S. 2003. Bacterial composition of commercial probiotic products as evaluated by PCR-DGGE analysis. Int. J. Food Microbiol. 82: 59-70. [Medline] [CrossRef]

12. Ghorbani, G. R., Morgavi, D. P., Beauchemin, K. A. and Leedle, J. A. Z. 2002. Effects of bacterial direct-fed microbials on ruminal fermentation, blood variables, and the microbial populations of feedlot cattle. J. Anim. Sci. 80: 1977-1985. [Medline]

13. Khafipour, E., Li, S., Plaizier, J. C. and Krause, D. O. 2009. Rumen microbiome composition determined using two nutritional models of subacute ruminal acidosis. Appl. Environ. Microbiol. 75: 7115-7124. [Medline] [CrossRef]

14. Koike, S., Pan, J., Kobayashi, Y. and Tanaka, K. 2003. Kinetics of in sacco fiber-attachment of representative ruminal cellulolytic bacteria monitored by competitive PCR. J. Dairy Sci. 86: 1429-1435. [Medline] [CrossRef]

15. Laarman, A. H., Sugino, T. and Oba, M. 2012. Effects of starch content of calf starter on growth and rumen $\mathrm{pH}$ in Holstein calves during the weaning transition. J. Dairy Sci. 95: 4478-4487. [Medline] [CrossRef]

16. Lane, D. J. 1991. pp.115-175. 16S/23S rRNA Sequencing in Nucleic Acid Techniques in Bacterial Systematic (Stackebrandt, E. and Goodfellow, M. eds.), Wiley, New York.

17. Leedle, J. A. Z., Barshun, K. and Hespell, R. B. 1986. Postprandial trends in estimated ruminal digesta polysaccharides and their relation to changes in bacterial groups and ruminal fluid characteristics. J. Anim. Sci. 62: 789-803. [Medline]

18. Lesmeister, K. E. and Heinrichs, A. J. 2004. Effects of corn processing on growth characteristics, rumen development, and rumen parameters in neonatal dairy calves. J. Dairy Sci. 87: 3439-3450. [Medline] [CrossRef]

19. Li, M., Penner, G. B., Sanabria, E. H., Oba, M. and Guan, L. L.
2009. Effects of sampling location and time, and host animal on assessment of bacterial diversity and fermentation parameters in the bovine rumen. J. Appl. Microbiol. 107: 1924-1934. [Medline] [CrossRef]

20. Mackie, R. I. and Gilchrist, F. M. C. 1979. Changes in lactateproducing and Lactate-utilizing bacteria in relation to $\mathrm{pH}$ in the rumen of sheep during stepwise adaptation to a high-concentrate diet. Appl. Environ. Microbiol. 38: 422-430. [Medline]

21. Martin, S. A. and Nisbet, D. J. 1992. Effect of direct-fed microbials on rumen microbial fermentation. J. Dairy Sci. 75: 1736-1744. [Medline] [CrossRef]

22. Matsuda, K., Tsuji, H., Asahara, T., Matsumoto, K., Takada, T. and Nomoto, K. 2009. Establishment of an Analytical System for the Human Fecal Microbiota, Based on Reverse Transcription-Quantitative PCR Targeting of Multicopy rRNA Molecules. Appl. Environ. Microbiol. 75: 1961-1969. [Medline] [CrossRef]

23. Matsuki, T., Watanabe, K., Fujimoto, J., Kado, Y., Takada, T., Matsumoto, K. and Tanaka, R. 2004. Quantitative PCR with 16S rRNA-gene-targeted species-specific primer for analysis of human intestinal bifidobacteria. Appl. Environ. Microbiol. 70: 167-173. [Medline] [CrossRef]

24. Mouriño, F., Akkarawongsa, R. and Weimer, P. J. 2001. Initial $\mathrm{pH}$ as a determinant of cellulose digestion rate by mixed ruminal microorganisms in vitro. J. Dairy Sci. 84: 848-859. [Medline] [CrossRef]

25. Nagaraja, T. G. and Titgemeyer, E. C. 2007. Ruminal acidosis in beef cattle: The current microbiological and nutritional outlook. J. Dairy Sci. 90 (Suppl. 1):E17-E38. [Medline] [CrossRef]

26. Nakanishi, S., Kuwahara, T., Nakayama, H., Tanaka, M. and Ohnishi, Y. 2005. Rapid species identification and partial strain differentiation of Clostridium butyricum by PCR using 16S23S rDNA intergenic spacer regions. Microbiol. Immunol. 49: 613-621. [Medline] [CrossRef]

27. Nocek, J. E., Kautz, W. P., Leedle, J. A. Z. and Allman, J. G. 2002. Ruminal supplementation of direct-fed microbials on diurnal $\mathrm{pH}$ variation and in situ digestion in dairy cattle. J. Dairy Sci. 85: 429-433. [Medline] [CrossRef]

28. Petri, R. M., Forster, R. J., Yang, W., McKinnon, J. J. and McAllister, T. A. 2012. Characterization of rumen bacterial diversity and fermentation parameters in concentrate fed cattle with and without forage. J. Appl. Microbiol. 112: 1152-1162. [Medline] [CrossRef]

29. Pitt, R. E. and Pell, A. N. 1997. Modeling ruminal pH fluctuations: Interactions between meal frequency and digestion rate. $J$. Dairy Sci. 80: 2429-2441. [Medline] [CrossRef]

30. Quigley, J. D., Steen, T. M. and Boehms, S. I. 1992. Postprandial changes in ruminating calves of selected blood and ruminal metabolites fed diet with or without hay. J. Dairy Sci. 75: 228-235. [Medline] [CrossRef]

31. Rinttilä, T., Kassinen, A., Malinen, E., Krogius, L. and Palva, A. 2004. Development of an extensive set of 16S rDNA-targeted primers for quantification of pathogenic and indigenous bacteria in faecal samples by real-time PCR. J. Appl. Microbiol. 97: 1166-1177. [Medline] [CrossRef]

32. Russell, J. B. and Wilson, D. B. 1996. Why are ruminal cellulolytic bacteria unable to digest cellulose at low pH? J. Dairy Sci. 79: 1503-1509. [Medline] [CrossRef]

33. Russell, J. B., O’Connor, J. D., Fox, D. G., Van Soest, P. J. and Sniffen, C. J. 1992. A net carbohydrate and protein system for evaluating cattle diets: Ruminal fermentation. J. Anim. Sci. 70: 3551-3561. [Medline]

34. Rustomo, B., AlZahal, O., Cant, J. P., Fan, M. Z., Duffield, T. F., Odongo, N. E. and cBride, B. W. 2005. Acidogenic value of 
feeds. II. Effects of rumen acid load from feeds on dry matter intake, ruminal $\mathrm{pH}$, fibre degradability and milk production in the lactating dairy cow. Can. J. Anim. Sci. 86: 119-126.

35. Sakamoto, M., Hayashi, H. and Benno, Y. 2003. Terminal restriction fragment length polymorphism analysis for human fecal microbiota and its application for analysis of complex bifidobacterial communities. Microbiol. Immunol. 47: 133-142. [Medline] [CrossRef]

36. Sato, S., Mizuguchi, H., Ito, K., Ikuta, K., Kimura, A. and Okada, K. 2012. Technical note: Development and testing of a radio transmission $\mathrm{pH}$ measurement system for continuous monitoring of ruminal pH in cows. Prev. Vet. Med. 103: 274-279. [Medline] [CrossRef]

37. Sharp, R., Hazlewood, G. P., Gilbert, H. J. and O’Donnell, A. G. 1994. Unmodified and recombinant strains of Lactobacillus plantarum are rapidly lost from the rumen by protozoal predation. J. Appl. Bacteriol. 76: 110-117. [Medline] [CrossRef]

38. Timmerman, H. M., Mulder, L., Everts, H., van Espen, D. C., van der Wal, E., Klaassen, G., Rouwers, S. M. G., Hartemink, R., Rombouts, F. M. and Beynen, A. C. 2005. Health and growth of veal calves fed milk replacers with or without probiotics. $J$. Dairy Sci. 88: 2154-2165. [Medline] [CrossRef]

39. Weinberg, Z. G., Muck, R. E. and Weimer, P. J. 2003. The survival of lactic acid bacteria in rumen fluid. J. Appl. Microbiol. 94: 1066-1071. [Medline] [CrossRef]

40. Weinberg, Z. G., Muck, R. E., Weimer, P. J., Chen, Y. and Gamburg, M. 2004. Lactic acid bacteria used in silage inoculants as probiotics for ruminants. Appl. Biochem. Biotechnol. 118: 1-9. [Medline] [CrossRef] 